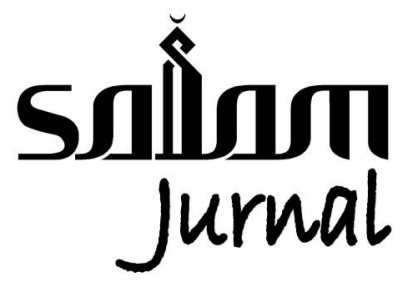

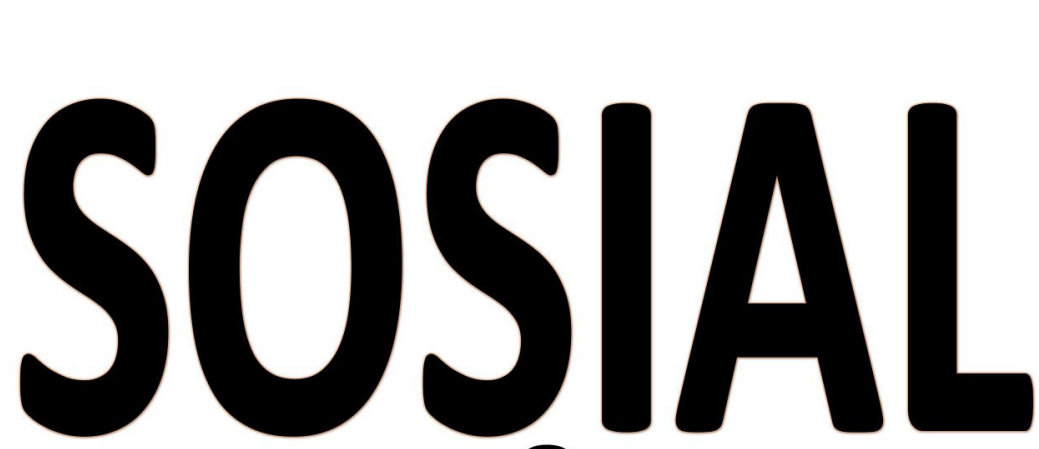

P-ISSN: 2356-1459 E-ISSN: $2654-9050$ Vol. 7 No. 4 (2020)
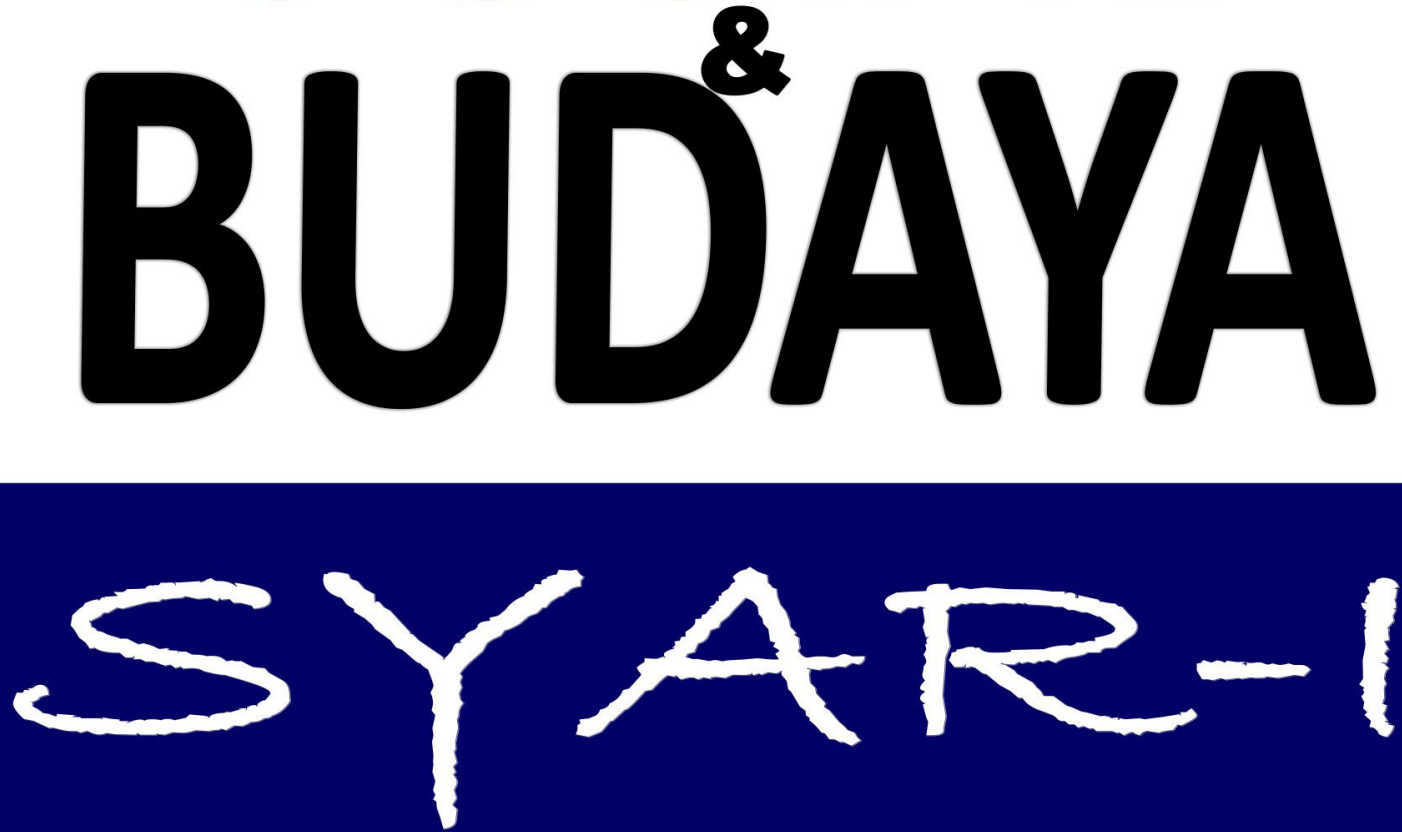

Pesona Tari sebagai Aset Pariwisata Budaya Indonesia

Pupitaning Wulan \& Warih Handayaningrum

Negosiasi Sosiologis Masyarakat Gresik dalam Seni Religi Hadrah

Agni Kusumawati \& Setyo Yanuartuti

Pemuliaan Islam Terhadap Kaum Wanita Dalam Perspektif Alquran dan Hukum Positif

Siti Ngainnur Rohmah

Accounts Payable (Qardh) in Islamic Law

Saprida, Choiriyah \& Melis

Kebijakan Pidana Dalam Pelanggaran Hak Cipta Di Indonesia

Yoyo Arifardhani

Alternatif Penyelesaian Sengketa sebagai Solusi Mewujudkan Asas Pemeriksaan Perkara -

"Sederhana, Waktu Singkat dan Biaya Murah"

Syafrida

Faktor Yang Mempengaruhi Nilai Perusahaan Dengan Corporate Social Responsibility Sebagai -

Variabel Moderating

Senja Nuansari 


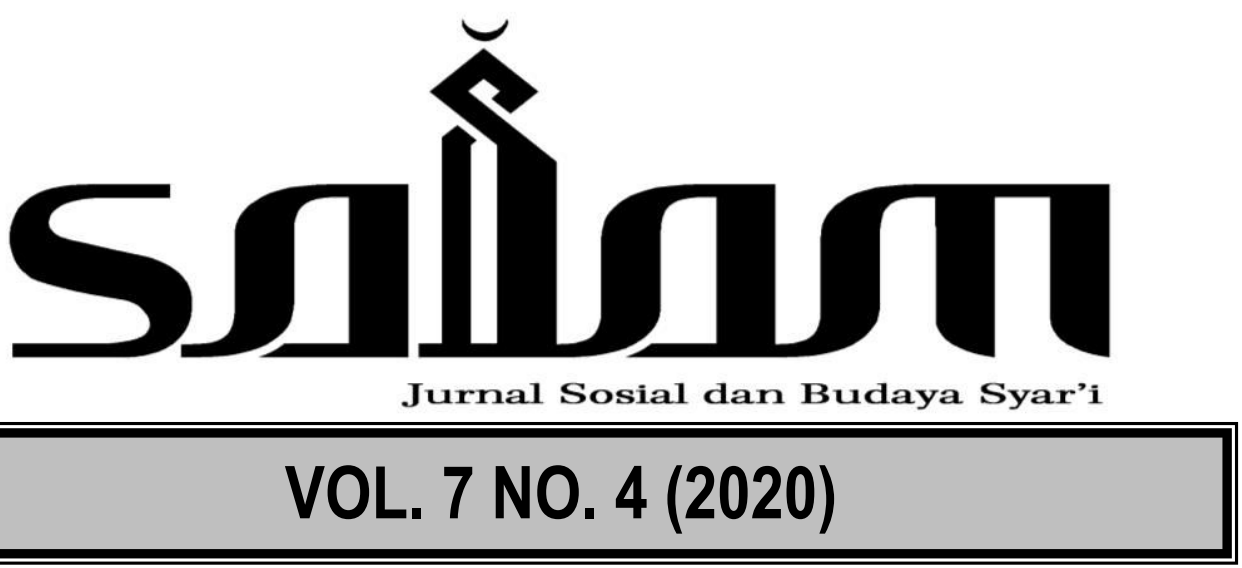

SALAM: Jurnal Sosial Budaya Syar-i (SJSBS) is an open access, and peer-reviewed journal. Our main goal is to disseminate current and original articles from researchers and practitioners on various contemporary social and sharia culture issues. SJSBS is published six times a year. It is nationally accredited by the Ministry of Research, Technology and Higher Education of the Republic of Indonesia (RISTEKDIKTI), No. 30/E/KPT/2019 (November 11, 2019). Submissions are open year-round. Before submitting, please ensure that the manuscript is in accordance with SJSBS's focus and scope and follows our author guidelines \& manuscript template.

SALAM: Jurnal Sosial Budaya Syar-i has become a CrossRef Member since year 2015. Therefore, all articles published by SALAM will have unique DOI number P-ISSN: 2356-1459 - E-ISSN: 2654-9050

\section{Reviewer}

Muhammad Amin Suma (UIN Syarif Hidayatullah Jakarta) A Salman Maggalatung (UIN Syarif Hidayatull ah Jakarta) Asep Saepudin Jahar (UIN Syarif Hidayatullah Jakarta) Ahmad Mukri Aji (UIN Syarif Hidayatullah Jakarta)

JM Muslimin (UIN Syarif Hidayatullah Jakarta)

Muhammad Munir (IIU Islamabad Pakistan)

Euis Amalia (UIN Syarif Hidayatullah Jakarta)

Tim Lindsey (Melbourne University Australia)

Raihanah Azahari (University Malaya Malaysia)

Ahmad Tholabi (UIN Syarif Hidayatullah Jakarta) Ahmad Hidayat Buang (University Malaya Malaysia)

\section{Editor In Chief} Erwin Hikmatiar

\section{Managing Editor}

Indra Rahmatullah

\section{Editors}

Muhammad Ishar Helmi

Mara Sutan Rambe

Nur Rohim Yunus

\section{Assistant to the Editors}

Imas Novita Juaningsih

Azizah Ratu Buana

\section{Alamat Redaksi}

Fakultas Syariah dan Hukum UIN Syarif Hidayatullah Jakarta

J1. Ir. H. Juanda 95 Ciputat Jakarta 15412 Telp. (62-21) 74711537, Faks. (62-21) 7491821 Website: http://journal.uinjkt.ac.id/index.php/salam, E-mail: jurnal.salam@uinjkt.ac.id 


\section{TABLE OF CONTENTS}

\section{3-298}

Pesona Tari sebagai Aset Pariwisata Budaya Indonesia

Pupitaning Wulan \& Warih Handayaningrum

\section{9-310}

Negosiasi Sosiologis Masyarakat Gresik dalam Seni Religi Hadrah

Agni Kusumawati \& Setyo Yanuartuti

\section{1-324}

Pemuliaan Islam Terhadap Kaum Wanita Dalam Perspektif Alquran dan Hukum Positif

Siti Ngainnur Rohmah

\section{5-334}

Accounts Payable (Qardh) in Islamic Law

Saprida, Choiriyah \& Melis

\section{5-352}

Kebijakan Pidana Dalam Pelanggaran Hak Cipta Di Indonesia

Yoyo Arifardhani

\section{3-370}

Alternatif Penyelesaian Sengketa sebagai Solusi Mewujudkan Asas

Pemeriksaan Perkara "Sederhana, Waktu Singkat dan Biaya Murah"

Syafrida

\section{1-394}

Faktor Yang Mempengaruhi Nilai Perusahaan Dengan Corporate Social Responsibility sebagai Variabel Moderating

Senja Nuansari 


\title{
Accounts Payable (Qardh) in Islamic Law
}

\author{
Saprida, ${ }^{1}$ Choiriyah, ${ }^{2}$ Melis $^{3}$ \\ $1{ }^{2}$ Sekolah Tinggi Ekonomi dan Bisnis Syariah Indo Global Mandiri Palembang \\ ${ }^{3}$ Universitas Islam Negeri Raden Fatah, Palembang \\ 10.15408/sjsbs.v7i4.15168
}

\begin{abstract}
This study discusses how accounts receivable (qardh) are in Islamic law. This research is a type of library research that focuses on qualitative data management with data analysis methods using the description-analysis method. The results of this study are that qardh (accounts receivable) is an act or activity that has the purpose of helping others who are in need of material assistance, and is highly recommended because it provides wisdom and benefits for the lender and the recipient of the debt. Qardh is permissible as long as there are no elements which are detrimental to either party. While the law exceeds the payment of as much debt, if the excess is indeed the will of the debtor and not the previous agreement, then the excess may be for those who repay it, and be good for those who pay the debt. As for the additions that are desired by those who are in debt or have become agreements during the contract, this must not be prohibited in Islam.
\end{abstract}

Keywords: Qardh, Islamic Law

\begin{abstract}
Abstrak
Penelitian ini membahas bagaimana piutang ( ardh) dalam hukum Islam. Penelitian ini adalah jenis penelitian kepustakaan yang berfokus pada manajemen data kualitatif dengan metode analisis data menggunakan metode deskripsi-analisis. Hasil penelitian ini adalah bahwa qardh (piutang dagang) adalah tindakan atau kegiatan yang memiliki tujuan membantu orang lain yang membutuhkan bantuan material, dan sangat dianjurkan karena memberikan kebijaksanaan dan manfaat bagi pemberi pinjaman dan penerima hutang. Qardh diperbolehkan selama tidak ada unsur yang merugikan salah satu pihak. Sementara hukum melebihi pembayaran hutang sebanyak-banyaknya, jika kelebihannya memang merupakan kehendak debitur dan bukan perjanjian sebelumnya, maka kelebihannya mungkin bagi mereka yang membayarnya, dan baik bagi mereka yang membayar hutang. Adapun tambahan yang diinginkan oleh mereka yang berhutang atau telah menjadi perjanjian selama kontrak, ini tidak boleh dilarang dalam Islam.
\end{abstract}

Kata Kunci: Qardh, Hukum Islam

*Diterima: 18 Maret 2020, Revisi: 20 Maret 2020, Diterbitkan 4 April 2020.

1 Saprida is a lecturer at Department of Sharia Economic, STEBIS IGM Palembang. E-mail: saprida@stebisigm.ac.id.

${ }^{2}$ Choiriyah is a lecturer at Department of Islamic Banking, STEBIS IGM Palembang. E-mail: choi@stebisigm.ac.id.

${ }^{3}$ Melis is a lecturer at Department of Sharia Economic, (FEBI) UIN Raden Fatah Palembang. Email: melis uin@radenfatah.ac.id 


\section{Introduction}

Islam regulates a strong relationship between morals, creed, worship, and muamalah. The muamalah aspect is the rule of the game for humans in carrying out social life, as well as being the basis for building an economic system following Islamic values. Muamalah teachings will keep humans from justifying any means to seek sustenance. Muamalah teaches humans to get a good fortune in a lawful and good way. It has been the will of Allah SWT that humans must live in society and help one another with one another. As social creatures, human beings accept and are fair in the lives of others, they interact with one another to meet the needs of life and achieve progress in their lives. To achieve progress and life goals, good cooperation is needed between human beings. Of the many aspects of cooperation, the most prominent among humans is the economic aspect. Islamic economics is dynamic according to the dimensions of space and time because Islam is rahmatan lil alamin. Islam regulates its economic system with a unique method. Islam views the economic problem not from a capitalist standpoint and neither from a socialist standpoint, but Islam justifies individual rights without damaging society. The concept of Islamic economics places both moral and material aspects of life as a basis for building economic power over moral values.

Accounts receivable payables refer to several bills to be received by the company (generally in cash) from other parties, both as a result of the delivery of goods and services on credit (for customer receivables consisting of trade receivables and allow receivable notes), providing loans (for receivables employee debtor debts which are usually directly in the form of notes receivable and interest receivables), as well as as a result of excess cash payments to other parties (for tax receivables). Most receivables arise from the delivery of goods and services on credit to customers. It is undeniable that in general customers will be more interested in buying a product offered on credit by the company (seller) and this also seems to be one of the tricks for the company to increase the amount of sales turnover that will appear in its profit and loss statement. Receivables arising from the sale of the delivery of goods and services on credit are classified as trade receivables, which they are not likely to change into notes receivable ${ }^{4}$

Discussions about accounts receivable debt have been carried out. Writing in the form of a journal written by Muhammad Rifqi Arriza (Journal of Islamic Law and Economics, 2015) titled "Theory and practice of the qardh contract (debts) in Islamic sharia" which discusses that the qardh contract has specific rules summarized in the definitions, conditions, harmony, the difference between the loan contract with other contracts, as well as the current contract application. So that this contract is one of the main choices in helping the dhu'afa who are struggling to get out of their economic problems. Aside from the loan receivable agreement, it can strengthen the kinship that has been lost. ${ }^{5}$

${ }^{4}$ Hery, Akuntansi : Aktiva, utang, dan modal (Yogyakarta: Gava Media, 2011), p. 36.

${ }^{5}$ Muhammad Rifqi Arriza, "Teori dan prektek akad qardh (hutang-piutang) dalam syariat Islam," Jurnal Hukum dan Ekonomi Islam, 2015. Lihat: A.S. Maggalatung; A.M. Aji; N.R. Yunus. How The Law Works, Jakarta: Jurisprudence Institute, 2014? Lihat juga: A.M. Aji; N.R. Yunus. Basic Theory of Law and Justice, Jakarta: Jurisprudence Institute, 2018. 
The 2015 Islamic Journal, written by Y. Sonafist, entitled "accounts receivable debt in the perspective of fiqh" discusses that, in general, scholars consider buying and selling credit receivables to people who are in debt, and illegally done to people who do not have debt responsibility. The main reason, in this case, is because the object of the transaction cannot be handed over. Malikiyah scholars allow it but with strict conditions. Departing from the Prophet's hadith about the sale and purchase of al-kalili-u bil klili-i. Wahbah, said that here is seen where the opinion of Malikiyah is the most effective among several schools. In practice it is not allowed to buy and sell debt with debt, such as selling debt to someone in a deferred manner; may not also translate debt into debt, such as the owner of the receivable hands over the debtor of the fruit he is quoting; or the house he occupies, to prolong his mastery. ${ }^{6}$

Writing in the form of a thesis, among others: "Perspective of Islamic Law Against Motorcycle Debt Financing Agreement (Al-Qard) at PT. Central Sentosa Finance West Surabaya branch ". Written by Meita Tantriani (2018) which discusses the financing of credit receivables (al-qard) motorcycle at PT. Central Sentosa Finance West Surabaya branch is a credit program given to consumers with a repayment period of seventeen months to twenty-three months. Based on the agreement of both parties at the beginning of the agreement, in the practice of financing debt receivables, there are practices of charging interest, charging late installments, and selling collateral when the debt is not repaid; secondly, the practice of charging interest in debt financing is contrary to Islamic law because it is usury. ${ }^{7}$

Next, the thesis entitled: "Legal Implementation of Inadequate Accounts Payable According to Imam Shafi'i (Case Study in Gunung Tua Village, Panyabungan District, Mandailing Natal Regency)". written by Silvia Novi Yanti (2018). Discussing the mechanism of the implementation of non-commensurable debt that exists in the community of Gunung Tua, Panyabungan district Mandailing Natal Regency is a debt receivable that is almost the same as the loan agreement in general, but the objects/goods used for debt are different, namely from the debt of goods with the repayment of different goods type because considering the different price changes, While muqridh does not want to know the price of the item does not match the price of the item borrowed at the time of its settlement. The factor in the occurrence of accounts payable and receivable is the business that is expected by the parties in debt to get the maximum profit. when the community is in a very urgent condition, this will be an opportunity for other communities to provide loans with certain conditions. And the public as a party who owes will agree to whatever the conditions are, as long as their needs can be met. ${ }^{8}$

Furthermore, the thesis entitled: "Overview of Islamic Law Against Conditional Debt Practices (Case Study in Tri Makmur Jaya Village, East Gala District, Tulang Bawang Regency)" written by Amelia Andriyani (2017). Concerning conditional debts

\footnotetext{
'Y. Sonafist, "utang piutang dalam perspektif fiqih," Jurnal Islamika, 2015.

${ }^{7}$ Meita Tantriani, "Perspektif Hukum Islam Terhadap Perjanjian Pembiayaan Hutang Piutang (AlQard) Sepeda Motor di PT. Central Sentosa Finance cabang Surabaya Barat.," 2018.

8Silvia Novi Yanti, "Hukum Pelaksanaan Akad Hutang Piutang yang Tidak Sepadan Menurut Imam Syafi'i (Studi Kasus di Desa Gunung Tua Kecamatan Panyabungan Kabupaten Mandailing Natal," 2018.
} 
that occur in the village of Tri Makmur Jaya, East Gala involves the creditor (skipper) as the person who gives the debt and the debtor (the person who owes). According to religious and community leaders, conditional debts carried out in the Tri Makmur Jaya village of East Galaala are not against Islamic law. Because conditional debts have become a good and mutually beneficial tradition for creditors and debtors, conditional debts have become a necessity or necessity for the villagers, if removed they will make it difficult for the community to fulfill their daily needs. ${ }^{9}$

\section{Definition of Qardh (Accounts Payable)}

Etymologically qardh is a mass form of qaradha ash-syai-yaqridhu, which means he decides it. Qard is a form of masdar which means to decide. It is said, qaradhu asyayai 'bil-miqradh, or break something with scissors. Al-qaradh is something that is given by the owner to be paid. The terminology is to give wealth to those who use it and return it later. ${ }^{10}$

According to Hanafiyah scholars, qard is something given by someone from Islamic wealth (who has something in common) to meet their needs. According to Rachmat Shafei, Qardh is a certain contract by paying Mitsli property to others to pay the same assets to him. According to Sayid Sabiq, the definition of qardh is assets given by the creditor (muqridh) to the recipient of the debt (muqtaridh) and then returned to him (muqridh) as he received it when he was able to pay it. ${ }^{11}$

According to the DSN-MUI fatwa, qardh is a loan agreement to the customer provided that the customer must return the funds received to the LKS at the time agreed upon by the LKS and the customer. According to Law No. 21 of 2008 concerning Sharia Banking, qard is a loan agreement fund to customers provided that the customer must return the funds received at the agreed time. ${ }^{12}$

\section{Basic Law of Qardh}

The legal basis for presenting qard is based on the Qur'an and Al-Hadith. The basis of the Qur'an is:

1. Surat Al-Baqarah verse 245, namely:

Meaning: Whoever wants to give a loan to Allah, a good loan (spends his wealth in the way of Allah), then Allah will multiply the payment to him with many double. And Allah narrows and gives (fortune) and you are returned to Him. ${ }^{13}$

\footnotetext{
${ }^{9}$ Amelia Andriyani, “Tinjauan Hukum Islam Terhadap Praktek Hutang Piutang Bersyarat (Studi Kasus di Desa Tri Makmur Jaya Kec. Menggala Timur Kabupaten Tulang Bawang)," 2017.

${ }^{10}$ Mardani, Figh Ekonomi Syariah figh Muamalah (Jakarta: Prenada Media Grouf, 2015), Hal. 331.

${ }^{11}$ Ahmad Wardi Muslich, Fiqh Muamalat (Jakarta: Amzah, 2015), p.273.

${ }^{12}$ Mardani, Hukum Sistem Ekonomi Islam (Jakarta: Raja Grafindo Persada, 2015), p.232.

${ }^{13}$ Depag RI, ed., Al-Quran dan Terjemahnya (Jakarta: Gema Risalah Press, 2000).
} 
2. The Word of God in Surah Al-Maidah verse 12:

It means: "Verily if you establish prayers and give alms and believe in My messengers and you help them and you lend to God a good loan. Surely I will cover your sins. And Verily, I will enter into heaven the waters that flow through the rivers. Then whoever disbelieves among you after that, Verily he has strayed from the straight path ". ${ }^{14}$

While the foundation of the hadith is as follows:

1. Hadith narrated from Ibn Mas'ud:

The Prophet SAW said: "A Muslim who is willing to give loans twice to fellow Muslims, so supposing he has given alms once" (HR. Ibn Majah and Ibn Hibban).

2. Hadith from Abu Hurairah:

The Prophet SAW said: "one who releases a Muslim from his troubles in the world, Allah will release his difficulties on the Day of Resurrection, and Allah always helps his servant as long as he likes to help his brother" (HR. Muslim, Abu Dawud, Turmizi). ${ }^{15}$

\section{Pillars and Qardh Transaction Terms}

Pillars of Qaradh are three, namely:

\section{Shihgat.}

What is meant by shihgat is consent and qabul. There is no difference between jurisprudence that the consent of the Kabul is valid with the lafaz of debt and with all lafaz that shows its meaning, such as the words, "I give you debt", or I owe you. " Likewise, Kabul is legitimate with all lafaz which shows willingness, such as "I owe" or I accept, "or" I am pleased "and so on.

2. 'Aqidain.

What is meant by 'aqidain (two parties conducting transactions) is the creditor and the debtor? The requirements for debtors are freedom, age, reason, and smart (rashid, can distinguish good from the bad).

3. The assets owed.

The pillars of assets to be debited are as follows:

a) Assets in the form of assets available to him, meaning that assets with each other in the same type are not much different which results in different values, such as money, items that can be measured, weighed, planted and counted.

\footnotetext{
${ }^{14}$ Imam Mustofa, Fiqih Mu'amalah Kontemporer (Jakarta: Raja Grafindo Persada, 2016), p.170.

${ }^{15}$ Dimyauddin Djuwaini, Pengantar Fiqih Muamalah (Yogyakarta: Pustaka Pelajar, 2010), p.255.
} 
b) Debt property is required in the form of objects, illegitimately benefits (services).

c) The assets that are owed are known, that is, the known and the properties are known. ${ }^{16}$

\section{Qardh's Law}

According to Imam Abu Hanifa and Muhammad, the new qard is effective and only binds when goods or money have been received. If someone borrows an amount of money and he has received it then the money becomes his property, and he is obliged to return it with the same amount of money (mitsli), not the money received. However, according to Imam Abu Yusuf Muqtaridh does not have the goods he owes (borrowed) if the goods are still there.

According to Malikiyah, the legal qardh is the same as a grant, sadaqah and 'ariyah, is valid and binding with the occurrence of a contract (ijab qabul), even though the muqtaridh has not received the goods. In this case, muqtaridh (the customer) may return the equality of the items borrowed, and may also return the type of goods, whether the goods are mitsli or ghair mitsli, if the goods have not changed with added or less. If the goods have changed, the muqtaridh must return the same item. ${ }^{17}$

In the authentic opinion of Shafi'yah and Hanabilah, ownership in qardh applies when the item has been received. Furthermore, according to Shafi'iyah, muqtaridh returns the same item if the item is Malitsli. If the goods are mal qimi, then he returns them with goods that are the same value as the items he borrowed. This is under the hadith of Abu Rafi ', where the Prophet SAW owed a virgin camel and then replaced it with a camel whose age is six to seven years. After that, the Prophet SAW said: "Indeed, the best person among you is the person who is the best at paying debts". (Narrated by Al-Bukhari). According to Hanabilah, the items measured and weighed, according to the fuqaha agreement, were returned with the same goods. Whereas in goods that are not measured and weighed, there are two opinions. First, it is returned with the price applicable at the time of debt. Second, returned with the same goods whose properties are close to the goods that are owned or borrowed ${ }^{18}$

\section{Adding Payment in Qardh}

Exceeding the payment of as much debt, if the excess is indeed the will of the debtor and not the previous agreement, then the excess maybe for those who repay it, and be good for those who pay the debt. As for the additional desired by the debtor or has become an agreement during the contract, it should not be. That addition is not

\footnotetext{
${ }^{16}$ Mardani, op. cit., 2015, p.333.

${ }^{17}$ Muslich, op. cit., p.280.

${ }^{18}$ Ibid., p.281.
} 
lawful for those who take the debt. For example, those who are in debt say to those who are in debt, "I repay you with the condition that when you pay you, you add more."

The Hadith of the Prophet said: It means: "Each receivable that takes benefits, then it is one of the many ways of usury."

From Abu Hurairah. He said: "The Messenger of Allah has owed animals, then he paid with animals that were older than the animal for which he was in debt, and the Messenger of Allah said," The best person among you is the one who pays his debt better" (History of Ahmad Tirmizi, then validated). ${ }^{19}$

\section{Debt Governance}

Several things become an emphasis in accounts receivable regarding manners related to it, including the following:

1) Loans should be made based on an urgent need accompanied by an intention in the heart to repay or repay.

2) The debtor should intend to assist the debtor. If the borrower has not been able to repay, the party giving the debt gives a time delay to pay it. And if the borrower is truly unable to repay, the lender should free him.

3) For the sake of maintaining good relations, the debts and debts should be strengthened by writing from both parties witnessed by two male witnesses or with a man and with two female witnesses.

4) When returning a debt or loan, the borrower should return the loan with the quality and quantity of the goods borrowed and if possible, as a thank you, the borrower will return the loan with better quality and quantity.

5) The debtor, if he has been able to repay a loan or debt, should accelerate repaying the debt because as explained in the hadith, neglecting to pay debts or loans, it means that he has committed wrongdoing to the lender or debt even though he helped. ${ }^{20}$

\section{Provisions of Qardh}

The qardh provisions according to the DSN fatwa are as follows:

First: General Provisions of Al-qardh; a). Al-qardh is a loan given to a customer (muqtaridh) in need; b). Al-qardh customers must return the principal amount received at the agreed time; c). Administration fees are charged to customers; d). LKS can request guarantees from customers whenever deemed necessary; e). Al-qardh customers can voluntarily provide additional (donations) to LKS as long as they are not agreed in the contract; f). If the customer is unable to return part or all of his obligations at the time

${ }^{19}$ Sulaiman Rasjid, Figh Islam (Bandung: Sinar Baru Algensindo, 1994), p.308.

${ }^{20}$ Abdul Rahman Ghazaly dan Dkk, Fiqh Muamalat (Jakarta: Prenada Media Grouf, n.d.), p.254. 
agreed upon and the LKS has confirmed its inability, the LKS can: Extend the return period, and Erase part or all of its obligations.

Second: Sanctions; a). If the customer does not show a desire to return some or all of his obligations and not because of his inability, the LKS can impose sanctions on the customer; b). Sanctions imposed on customers as referred to in point 1 can be in the form of, and are not limited to, sales of collateral; c). If the collateral is insufficient, the customer must still fulfill his obligations in full.

Third: Source of Funds. Al-Qard funds can be sourced from; a). Equity capital LKS; b). LKS profits set aside; c). Other institutions or individuals who entrust the distribution of infaq to LKS.

Fourth: a). If one party does not fulfill its obligations or if there is a dispute between the parties, the settlement is carried out through the Sharia Arbitration Body after no agreement is reached through deliberation; $b$ ). This fatwa is effective from the date it is stipulated that if it turns out that it can later be made in error, it will be amended and perfected accordingly. ${ }^{21}$

\section{Wisdom and Benefits Required Qardh}

The wisdom of the qardh is as follows; a). Carry out the will of Allah so that Muslims help one another in goodness and piety; b). Strengthen the bond of brotherhood by extending help to people in need and experiencing difficulties and alleviating the burden of people who are being hit by difficulties. ${ }^{22}$

\section{Qardh Application in Islamic Banking}

The qardh contract is usually applied to the following matters; a). As a complementary product to customers who have proven loyalty and reliability, who need an immediate bailout for a relatively short period. The customer will immediately return the amount of money he borrowed; b). As a customer facility that requires fast funds, while he cannot withdraw funds because, for example, is stored in the form of deposits; c). As a product to contribute to very small businesses or help the social sector. ${ }^{23}$

\section{Benefits of Qardh in the Business World}

Qardh provides benefits for the community and Islamic banks themselves. Benefits of Qardh include;

1. Helping customers when they have difficulties by providing short-term bailouts.

\footnotetext{
${ }^{21}$ Mardani, op. cit., 2015, p.235.

22Mardani, op. cit., 2015.

${ }^{23}$ Ibid., p.235.
} 
2. Small traders get help from Islamic banks to develop their businesses, so it is a social mission for Islamic banks to help the poor.

3. Can divert small traders from debt loan sharks, by getting debt from Islamic banks.

4. Increase public loyalty to Islamic banks, because Islamic banks can provide benefits to the poor.

\section{The view of Islamic law towards Qardh}

Qardh (accounts receivable) in syara terms' means something given to someone else (which must one day be returned). ${ }^{24}$ In borrowing loans, it is permissible to provide conditions for guarantees and guarantors, and may not, submit conditions for meeting inside, and may not also propose conditions for benefits. ${ }^{25}$

Debts in Islam are one type of approach to be patient with Allah SWT, by being gentle to humans, loving and providing comfort from the sorrow that surrounds them, all of which are intended only to get the pleasure of Allah SWT alone. Sometimes in daily life requires the existence of a debt to meet daily needs, then Islam provides rules about this problem. Punishments Receivable debt is originally allowed in Islamic law. Even people who give loans or loans to others who need it are things that are liked and recommended because in it there is a large reward.

\section{Conclusion}

Qardh (accounts payable) is an act or activity that has the purpose of helping others who require assistance in the form of material and is highly recommended because it provides wisdom and benefits for lenders and debt recipients. Qardh is permitted as long as there are no elements that are detrimental to either party. Qardh is permitted as long as there are no elements that are detrimental to either party. While the law exceeds the payment of as much debt, if the excess is indeed the will of the debtor and not the previous agreement, then the excess maybe for those who repay it, and be good for those who pay the debt. As for the additions that are desired by those who are in debt or have become agreements during the contract, this must not be prohibited in Islam.

\section{References}

Andriyani, Amelia. "Tinjauan Hukum Islam Terhadap Praktek Hutang Piutang Bersyarat (Studi Kasus di Desa Tri Makmur Jaya Kec. Menggala Timur Kabupaten Tulang Bawang)," 2017.

${ }^{24}$ Muslich, op. cit., p.274.

${ }^{25}$ Abu Ishaq Asy-Syurazi, Al-Muhadzdzab Kunci Fiqih Syafi'i, juz-2 (Semarang: CV Asy Syfa, 1992), p.304. 
Aji, A.M.; Yunus, N.R. Basic Theory of Law and Justice, Jakarta: Jurisprudence Institute, 2018.

Arriza, Muhammad Rifqi. "Teori dan prektek akad qardh (hutang-piutang) dalam syariat Islam." Jurnal Hukum dan Ekonomi Islam, 2015.

Asy-Syurazi, Abu Ishaq. Al-Muhadzdzab Kunci Fiqih Syafi'i, juz-2. Semarang: CV Asy Syfa, 1992.

Djuwaini, Dimyauddin. Pengantar Fiqih Muamalah. Yogyakarta: Pustaka Pelajar, 2010.

Ghazaly, Abdul Rahman, dan Dkk. Figh Muamalat. Jakarta: Prenada Media Grouf, n.d.

Hery. Akuntansi : Aktiva, utang, dan modal. Yogyakarta: Gava Media, 2011.

Mardani. Figh Ekonomi Syariah figh Muamalah. Jakarta: Prenada Media Grouf, 2015.

Mardani. Hukum Sistem Ekonomi Islam. Jakarta: Raja Grafindo Persada, 2015.

Maggalatung, A.S.; Aji, A.M.; Yunus, N.R. How The Law Works, Jakarta: Jurisprudence Institute, 2014.

Muslich, Ahmad Wardi. Figh Muamalat. Jakarta: Amzah, 2015.

Mustofa, Imam. Fiqih Mu'amalah Kontemporer. Jakarta: Raja Grafindo Persada, 2016.

Rasjid, Sulaiman. Figh Islam. Bandung: Sinar Baru Algensindo, 1994.

RI, Depag, ed. Al-Quran dan Terjemahnya. Jakarta: Gema Risalah Press, 2000.

Sonafist, Y. “utang piutang dalam perspektif fiqih.” Jurnal Islamika, 2015.

Tantriani, Meita. "Perspektif Hukum Islam Terhadap Perjanjian Pembiayaan Hutang Piutang (Al-Qard) Sepeda Motor di PT. Central Sentosa Finance cabang Surabaya Barat.," 2018.

Yanti, Silvia Novi. "Hukum Pelaksanaan Akad Hutang Piutang yang Tidak Sepadan Menurut Imam Syafi'i (Studi Kasus di Desa Gunung Tua Kecamatan Panyabungan Kabupaten Mandailing Natal," 2018. 


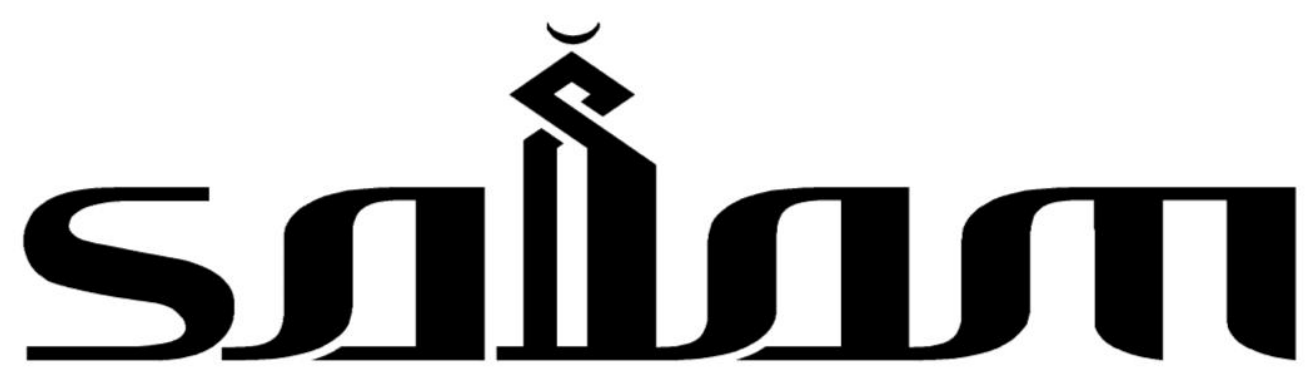

Jumnal Sosial dan Budaya Syar'i

\section{PEDOMAN TEKNIS PENULISAN BERKALA ILMIAH}

1. Artikel adalah benar-benar karya asli penulis, tidak mengandung unsur plagiasi, dan belum pernah dipublikasikan dan/atau sedang dalam proses publikasi pada media lain yang dinyatakan dengan surat pernyataan yang ditandatangani di atas meterai Rp 6000;

2. Naskah dapat berupa konseptual, resume hasil penelitian, atau pemikiran tokoh;

3. Naskah dapat berbahasa Indonesia, Inggris, Arab, maupun bahasa Rusia;

4. Naskah harus memuat informasi keilmuan dalam ranah ilmu hukum Positif;

5. Aturan penulisan adalah sebagai berikut:

a. Judul. Ditulis dengan huruf kapital, maksimum 12 kata diposisikan di tengah (centered);

b. Nama penulis. Ditulis utuh, tanpa gelar, disertai afiliasi kelembagaan dengan alamat lengkap, dan alamat e-mail;

c. Abstrak. Ditulis dalam bahasa Inggris dan Bahasa Indonesia antara 80-120 kata;

d. Sistematika penulisan naskah adalah sebagai berikut:

1) Judul;

2) Nama penulis (tanpa gelar akademik), nama dan alamat afiliasi penulis, dan e-mail;

3) Abstrak ditulis dalam dua bahasa, yaitu bahasa Indonesia dan Inggris, antara 80-120 kata;

4) Kata-kata kunci, antara 2-5 konsep yang mencerminkan substansi artikel;

5) Pendahuluan;

6) Sub judul (sesuai dengan keperluan pembahasan);

7) Penutup; dan

8) Pustaka Acuan (hanya memuat sumber-sumber yang dirujuk dan sedapat mungkin terbitan 10 tahun terakhir).

e. Ukuran kertas yang digunakan adalah kertas HVS 70 gram, ukuran A4, margin: atas $3,5 \mathrm{~cm}$, bawah $3.5 \mathrm{~cm}$, kiri $3,5 \mathrm{~cm}$, dan kanan $3,5 \mathrm{~cm}$;

f. Panjang Naskah antara 13 s.d. 15 halaman, spasi 1, huruf Palatino, ukuran 11;

g. Pengutipan kalimat. Kutipan kalimat ditulis secara langsung apabila lebih dari empat baris dipisahkan dari teks dengan jarak satu spasi dengan ukuran huruf 10 point. Sedangkan kutipan kurang dari empat baris diintegrasikan dalam teks, dengan tanda apostrof ganda di awal dan di akhir kutipan. Setiap kutipan diberi nomor. Sistem pengutipan adalah footnote (bukan bodynote atau endnote). Penulisan footnote menggunakan sistem turabian. Setiap artikel, buku, dan sumber lainnya yang dikutip harus tercantum dalam pustaka acuan;

h. Pengutipan Ayat Alquran dan Hadis. Ayat yang dikutip menyertakan keterangan ayat dalam kurung, dengan menyebut nama surah, nomor surah, dan nomor ayat, seperti (Q.s. al-Mu'min [40]: 43). Pengutipan Hadis menyebutkan nama perawi (H.r. al-Bukhārĩ dan Muslim) ditambah referensi versi cetak kitab Hadis yang dikutip. Hadis harus dikutip dari kitab-kitab Hadis standar (Kutub al-Tis'ah);

i. Cara pembuatan footnote. Footnote ditulis dengan font Palation size 9, untuk pelbagai sumber, antara lain: 
1) Buku: nama utuh penulis (tanpa gelar), judul buku (tempat terbit: penerbit, tahun terbit), cetakan, volume, juz, halaman. Contoh: Soerjono Soekanto, Pokok-pokok Sosiologi Hukum, (Jakarta: Rajawali Pers, 1986), h. 10.

2) Buku terjemahan, contoh: Roscoe Pound, Pengantar Filsafat Hukum: Buku III, diterjemahkan oleh Moh. Radjab, (Jakarta: Bharata, 1963), h. 15;

1) Jurnal, contoh: Nur Rohim, "Kontroversi Pembentukan Perppu No. 1 Tahun 2013 tentang mahkamah konstitusi dalam ranah kegentingan yang memaksa", dalam Jurnal Cita Hukum, Vol. 2, No. 1 (2014), h. 157.

2) Artikel sebagai bagian dari buku (antologi), contoh: Hikmahanto Juwana, "Penegakan Hukum dalam Kajian Law and Development: Problem dan Fundamen bagi Solusi Indonesia", dalam Muhammad Tahir Azhary, Beberapa Aspek Hukum Tata Negara, Hukum Pidana, dan Hukum Islam, (Jakarta: Kencana Prenada Media Gorup, 2012), h. 127.

3) Artikel dari internet, contoh: Ahmad Tholabi Kharlie, "Problem Yuridis RUU Syariah" dalam http://ahmadtholabi.com/2008/03/03/problem-yuridis-ruu-syariah, diunduh pada 20 Maret 2012.

4) Artikel dari majalah, contoh: Susilaningtias, "Potret Hukum Adat pada Masa Kolonial", dalam Forum Keadilan, No. 17, 20 Agustus 2006.

5) Makalah dalam seminar, contoh: Jimly Asshiddiqie, "Kedudukan Mahkamah Konstitusi dalam Struktur Ketatanegaraan Indonesia", Makalah disampaikan dalam Kuliah Umum Fakultas Hukum Universitas Sebelas Maret, Surakarta, pada 2 Maret 2004.

j. Pustaka Acuan: daftar pustaka acuan ditulis sesuai urutan abjad, nama akhir penulis diletakkan di depan. Contoh:

1) Buku, contoh: Soekanto, Soerjono, Pokok-pokok Sosiologi Hukum, Jakarta: Rajawali Pers, 1986.

2) Buku terjemahan, contoh: Pound, Roscoe, Pengantar Filsafat Hukum: Buku III, diterjemahakan oleh Moh. Radjab, Jakarta: Bharata, 1963.

3) Jurnal, contoh: Rohim, Nur, "Kontroversi Pembentukan Perppu No. 1 Tahun 2013 tentang mahkamah konstitusi dalam ranah kegentingan yang memaksa", dalam Jurnal Cita Hukum, Vol. 2, No. 1 (2014).

4) Artikel sebagai bagian dari buku, contoh: Juwana, Hikmahanto, "Penegakan Hukum dalam Kajian Law and Development: Problem dan Fundamen bagi Solusi Indonesia", dalam Muhammad Tahir Azhary, Beberapa Aspek Hukum Tata Negara, Hukum Pidana, dan Hukum Islam, Jakarta: Kencana Prenada Media Gorup, 2012.

5) Artikel yang dikutip dari internet, contoh: Kharlie, Ahmad Tholabi, "Problem Yuridis RUU Syariah" dalam http://ahmadtholabi.com/2008/03/03/problem-yuridis-ruu-syariah, diunduh pada 20 Maret 2012.

6) Majalah, contoh: Susilaningtias, "Potret Hukum Adat pada Masa Kolonial", dalam Forum Keadilan, No. 17, 20 Agustus 2006.

7) Makalah dalam seminar, contoh: Asshiddiqie, Jimly, "Kedudukan Mahkamah Konstitusi dalam Struktur Ketatanegaraan Indonesia", Makalah disampaikan dalam Kuliah Umum Fakultas Hukum Universitas Sebelas Maret, Surakarta, pada 2 Maret 2004.

k. Penutup: artikel ditutup dengan kesimpulan;

I. Biografi singkat: biografi penulis mengandung unsur nama (lengkap dengan gelar akademik), tempat tugas, riwayat pendidikan formal (S1, S2, S3), dan bidang keahlian akademik;

6. Setiap naskah yang tidak mengindahkan pedoman penulisan ini akan dikembalikan kepada penulisnya untuk diperbaiki.

7. Naskah sudah diserahkan kepada penyunting, selambat-lambatnya tiga bulan sebelum waktu penerbitan (April, Agustus. dan Desember) dengan mengupload pada laman OJS jurnal pada alamat http://journal.uinjkt.ac.id/index.php/salam atau dikirim langsung via e-mail ke: jurnal.salam@gmail.com atau nurrohimyunus@uinjkt.ac.id..] 


\section{Indexed by :}
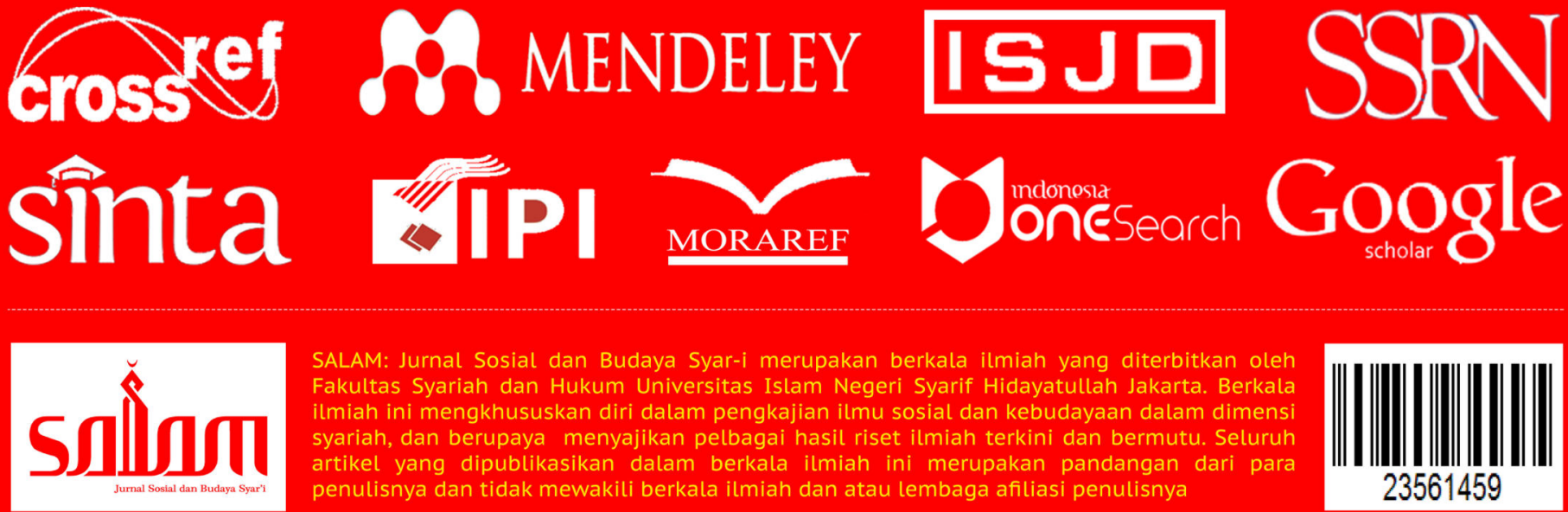

SALAM: Jurnal Sosial dan Budaya Syar-i merupakan berkala ilmiah yang diterbitkan oleh Fakultas Syariah dan Hukum Universitas Islam Negeri Syarif Hidayatullah Jakarta. Berkala ilmiah ini mengkhususkan diri dalam pengkajian ilmu sosial dan kebudayaan dalam dimensi syariah, dan berupaya menyajikan pelbagai hasil riset ilmiah terkini dan bermutu. Seluruh artikel yang dipublikasikan dalam berkala ilmiah ini merupakan pandangan dari para penulisnya dan tidak mewakili berkala ilmiah dan atau lembaga afiliasi penulisnya

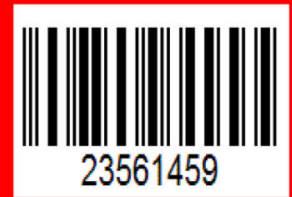

